\title{
SUPPORTIVE MOVES IN THE SPEECH ACT OF DIRECT COMPLAINT IN ENGLISH AND SERBIAN: A CROSS-CULTURAL AND INTERLANGUAGE PRAGMATIC ANALYSIS**
}

This paper examines the use of supportive moves in the speech act of direct, face-to-face complaints produced by English and Serbian native speakers in their respective mother tongues, highlighting similarities and differences in their performance. The study also explores how advanced Serbian L1 learners of English use supportive moves in complaints performed in English and especially, whether and to what extent they apply the pragmatic rules of their native language (pragmatic transfer) in doing so. Data were collected through discourse completion tasks (DCTs). The performance of all three groups of participants is compared, with special focus on the contextual variables of social power and severity of complaint. The results of the research indicate that the two cultures are similar with respect to the production of direct complaints, as well as that a low level of pragmatic transfer is observable in the complaint production of the English learners' group. In order to avoid pragmatic failure in communication in the target language in general, L2 learners need to be exposed to explicit instruction regarding both the linguistic and the cultural conventions in the foreign language, supported by authentic and suitable teaching materials.

Key words: speech act, complaint, supportive moves, English language, Serbian language, Serbian EFL learners

\section{PURPOSE AND RESEARCH QUESTIONS}

This study examines the use of supportive moves in direct, face-to-face complaints produced by native speakers (NSs) of Serbian and NSs of English, as

\footnotetext{
*milkenzi@gmail.com

${ }^{* *}$ This paper was presented at the 5th International Conference on English Language and Anglophone Literatures Today (ELALT 5) held at the Faculty of Philosophy in Novi Sad on March 9, 2019.
} 
well as advanced Serbian EFL learners, which is an important aspect since many foreign language (FL) learners do not manage to acquire a high level of pragmatic competence despite a rather high level of linguistic competence. Therefore, they often rely on the rules of their native language and culture (Olshtain \& Weinbach 1993, Tanck 2002, Al-Tayib Umar 2006), which is known as pragmatic transfer. It is a phenomenon that can reflect negatively on communication as cultures around the world differ and what is considered acceptable in one culture may not be equally acceptable in another.

The data collected in this research are to be analyzed in terms of House \& Kasper's (1981) classification of supporting moves found in speech acts while paying special attention to the social variables of power and severity of offense. Potential differences are expected to be observed in the performance of the two NS groups, as well as a certain amount of pragmatic transfer in the EFL group. This paper is significant since the speech act of complaint remains rather underexplored in the production of Serbian L1 learners of English (see next section.)

\section{DEFINING RELEVANT NOTIONS}

To begin with, Crystal (1997) defines pragmatics as:

the study of language from the point of view of users, especially of the choices they make, the constraints they encounter in using language in social interaction and the effects their use of language has on other participants in the act of communication. (Crystal, 1997: 301)

While rules of syntax or vocabulary are easier to identify, recognizing rules of pragmatics can be challenging. This can lead to the inappropriate use of vocabulary/grammar but also to failure to adhere to L2 pragmatic norms, which may result in the FL learner being perceived as ignorant or impolite. Therefore, FL learners need to be aware of FL linguistic and cultural conventions when producing speech acts.

Speech act theory was introduced by Austin (1962) and later developed by Searle $(1969,1975,1976)$. It deals with the actual communicative function of language rather than units as isolated phrases and their literal meaning. According to Austin (1962), an utterance has three functions: locutionary (uttering the actual words), illocutionary (what the speaker means/implies by uttering the words), and perlocutionary (the actual effect of the utterance on the hearer). How successful a speech act is depends upon the hearer's ability to grasp the intended meaning. As for the speech act of complaint, it is defined as "an illocutionary act in which the 
speaker expresses his/her disapproval, negative feelings, etc. toward the state of affairs described in the proposition and for which he/she holds the hearer responsible, either directly or indirectly" (Trosborg, 1995: 174). Therefore, a complaint is a face-threatening act (FTA). Brown \& Levinson (1987: 65) define FTAs as speech acts "that by their nature run contrary to the face wants of the addressee and/or of the speaker."

Many linguists have studied complaints from various perspectives. It has often been reported that more attention should be dedicated to improving learners' pragmatic competence. For example, Piotrowska's (1987) studied Cantonese EFL learners and their sociolinguistic competence. Complaints produced by English NSs and EFL learners differed concerning social distance and situational context and this was found to be due to different sociocultural norms in the two languages.

In addition, Trosborg (1995) focused on complaints produced by NSs of English, NSs of Danish, and Danish EFL learners. She found that the EFL learners used fewer complaint strategies and modifications than the NS groups. Moreover, the two NS groups differed regarding the use of strategies when communicating with an interlocutor of higher status - the English NSs were most likely to employ indirect strategies in this case, unlike the Danish NSs, who mostly relied on using direct strategies.

Tanck (2002) investigated how adult English NSs and adult EFL speakers perform refusals and complaints. The findings of her study indicate that the nonnative speakers' (NNS) responses, although generally linguistically correct, differed from the NSs' responses concerning pragmatic elements. For instance, NNSs' complaints were usually longer, whereas their complaints directed at an addressee of higher status were often considered inappropriate (too direct).

Eshraghi \& Shahrokhi (2016) explored complaining strategies in Iranian female EFL learners and female NSs of English. Notable differences were found concerning the frequency of the strategies used. The two groups may simply have had different attitudes due to different cultural/religious contexts. However, it is more probable that EFL learners should receive better pragmatic instruction and develop pragmatic competence leading to higher proficiency.

Serbian linguists have analyzed various speech acts, but complaints are not commonly researched. Prodanović examined the speech act among several other FTAs as part of her doctoral dissertation (2014), as well as the function of pragmatics in L2 acquisition through the prism of complaints (2016). The former study describes strategies and mitigation devices used by NSs of Serbian and NSs of the British and American dialects of English. Namely, the paper shows that 
Serbian NSs produce FTAs more directly and with fewer mitigating devices than NSs of English. Prodanović (2016) compared the performance of English NSs and Croatian/Bosnian/Serbian EFL learners, presuming there will be notable differences in the use of complaint strategies. In contrast, the present study deals with complaints only, offering a more thorough depiction of the use of supporting moves, and it pays special attention to NNSs' pragmatic competence and potential pragmatic transfer.

Moreover, this paper focuses on supportive moves suggested by House \& Kasper (1981: 166) - elements modifying speech acts that can be omitted without affecting the illocutionary force of the utterance. The authors refer to those elements as downgraders in case they lower the impact of the speech act, or upgraders if they increase its impact. House and Kasper's (1981) taxonomy is given in the table below.

Table 1. Supportive moves by House \& Kasper (1981)

\begin{tabular}{|c|c|c|}
\hline \multicolumn{3}{|c|}{ Supportive moves } \\
\hline Category & Explanation & Devices \\
\hline \multicolumn{3}{|l|}{ Downgraders } \\
\hline politeness marker & $\begin{array}{c}\text { used to show deference to } \\
\text { the hearer and to ask } \\
\text { cooperation }\end{array}$ & please \\
\hline understater & $\begin{array}{l}\text { an adverbial modifier used to } \\
\text { mitigate the state of affairs } \\
\text { in the utterance }\end{array}$ & $\begin{array}{c}\text { a (little) bit, not very much, } \\
\text { maybe }\end{array}$ \\
\hline hedge & $\begin{array}{c}\text { used to avoid a precise } \\
\text { specification in the utterance } \\
\text { to avoid potential } \\
\text { provocation }\end{array}$ & $\begin{array}{l}\text { just, like, somehow, kind of, } \\
\text { and so on, rather }\end{array}$ \\
\hline subjectivizer & $\begin{array}{l}\text { used to inform the hearer the } \\
\text { utterance is the speaker's } \\
\text { subjective opinion }\end{array}$ & $\begin{array}{c}\text { I think / believe / suppose / } \\
\text { wonder /guess }\end{array}$ \\
\hline downtoner & $\begin{array}{c}\text { a sentential modifier used to } \\
\text { mitigate the impact of the } \\
\text { speech act }\end{array}$ & perhaps, simply, just \\
\hline cajoler & $\begin{array}{l}\text { used to increase or restore } \\
\text { harmony between the } \\
\text { speaker and the hearer }\end{array}$ & You know, You see, I mean \\
\hline appealer & $\begin{array}{l}\text { used by the speaker to } \\
\text { appeal to the hearer's } \\
\text { benevolent understanding }\end{array}$ & question tags, ok/right? \\
\hline scope-starter & $\begin{array}{l}\text { used to exhibit the } \\
\text { subjectivity of the speaker's } \\
\text { opinion and explain the state } \\
\text { of affairs in the proposition }\end{array}$ & $\begin{array}{c}\text { I'm afraid, I'm not happy } \\
\text { about }\end{array}$ \\
\hline
\end{tabular}


SUPPORTIVE MOVES IN THE SPEECH ACT OF DIRECT COMPLAINT IN ... $\mid 117$

\begin{tabular}{ccc}
\hline Upgraders & adverb used to intensify \\
\hline intensifier & $\begin{array}{c}\text { particular elements of the } \\
\text { proposition }\end{array}$ & $\begin{array}{c}\text { very, so, really, absolutely, } \\
\text { quite, indeed }\end{array}$ \\
\hline commitment indicator & $\begin{array}{c}\text { a sentential modifier used to } \\
\text { show the speaker has a high } \\
\text { commitment to the state of } \\
\text { affairs }\end{array}$ & $\begin{array}{c}\text { I'm sure, certainly, } \\
\text { obviously }\end{array}$ \\
\hline expletive & $\begin{array}{c}\text { a lexical item used to } \\
\text { express negative social } \\
\text { attitude }\end{array}$ & bloody, damn \\
\hline time intensifier & $\begin{array}{c}\text { used to make a time } \\
\text { expression more intense } \\
\text { gives the proposition } \\
\text { negative connotations }\end{array}$ & right now, immediately \\
\hline determination marker & $\begin{array}{c}\text { increases the degree of the } \\
\text { speaker's determinants }\end{array}$ & Clean up the mess. \\
\hline emphatic addition & $\begin{array}{c}\text { used to give additional } \\
\text { emphasis to the proposition }\end{array}$ & That's that! \\
\hline
\end{tabular}

All in all, a complaint can include different (combinations of) modifying elements some of which are used to soften the FTA, while others intensify it.

\section{METHODOLOGY}

This study involved three groups of participants: NSs of English and NSs of Serbian, as well as advanced Serbian learners of English - students in their $4^{\text {th }}$ year or master's studies at the English Department of the Faculty of Philosophy, University of Novi Sad, all at C2 level of English according to the Common European Framework for Reference for Languages (CEFR). Participation in this research was voluntary.

Table 2. Information about the participants

\begin{tabular}{|c|c|c|c|c|}
\hline \multirow{2}{*}{ Participants } & \multirow{2}{*}{ Total number } & \multirow{2}{*}{ Average age } & \multicolumn{2}{|c|}{ Gender } \\
\hline & & & $\mathbf{M}$ & $\mathbf{F}$ \\
\hline NSs of English & 13 & 41.15 & 4 & 9 \\
\hline NSs of Serbian & 24 & 26.96 & 3 & 21 \\
\hline Advanced Serbian EFL learners & 22 & 23.82 & 3 & 19 \\
\hline TOTAL & 59 & 30.64 & $17 \%$ & $83 \%$ \\
\hline
\end{tabular}


eager to participate than men. The same applies to the third group, but female students at the English Department in Novi Sad are generally more numerous than male students, so the uneven distribution of the genders was expected.

As for the variables used in this research, $\mathrm{P}$ marks the power relation holding between the interlocutors. This study involved interlocutors of equal power $(\mathrm{P}=)$ or unequal power $(\mathrm{P}+$ when the speaker was superior and $\mathrm{P}-$ when they were inferior). Unequal power relations are typically illustrated by communication between an employer and an employee or a professor and a student, while $\mathrm{P}=$ usually involves communication between friends or roommates. The second variable, marked as $\mathrm{S}$, relates to the severity of an offense (what the hearer has done to motivate the complaint). $\mathrm{S}$ is a binary category in this research and offenses are taken to be more or less severe $(\mathrm{S}+/-)$. Since this notion may be quite subjective, either distinctly serious or trivial offenses were used to elicit clearer responses.

Responses were collected through a method called discourse completion task (DCT). Kasper \& Dahl (1991) interpret it as a questionnaire with short descriptions of a situation aiming to reveal the pattern of the speech act analyzed. DCTs can take a written or an oral form and respondents are allowed to not provide a response at all. Our questionnaire (see Appendix) offered 24 scenarios that could be categorized into six groups of four questions, each based on the following variable combinations: $\mathrm{P}+\mathrm{S}+, \mathrm{P}+\mathrm{S}-, \mathrm{P}=\mathrm{S}+, \mathrm{P}=\mathrm{S}-, \mathrm{P}-\mathrm{S}+, \mathrm{P}-\mathrm{S}-$. The situations were presented in the questionnaires in random order. The Serbian NS group received the Serbian version of the questionnaire via Google Forms (back translation was used to ensure that the situations translated into Serbian matched the ones in English), while the NSs of English and the group of EFL learners completed the English version. Each response was carefully analyzed, noting all instances of supporting moves, which were subsequently classified into the appropriate categories and analyzed using descriptive statistics. The results and their interpretation are presented in the following section.

\section{RESULTS}

The three groups' complaints were examined based on the supporting moves (downgraders and upgraders) described earlier. The performance of the groups differed with respect to several elements, which we discuss in separate headings for each group of research participants.

\subsection{English NSs}


The English NSs' responses are discussed first. The following table offers the exact number of instances in which each of the supportive moves was employed.

Table 3. Supportive moves in the complaints of the English NSs

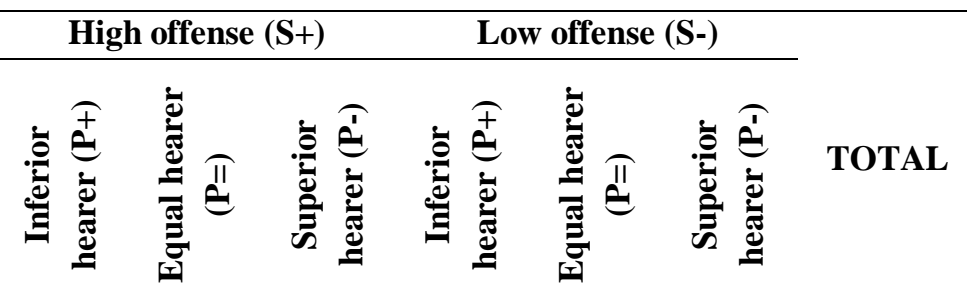

\begin{tabular}{|c|c|c|c|c|c|c|c|}
\hline Downgraders & & & & & & & \\
\hline Politeness marker & 11 & 1 & 7 & 14 & 1 & 4 & 38 \\
\hline Understater & & & 1 & & 2 & 2 & 5 \\
\hline Hedge & 1 & 2 & 18 & 3 & 1 & 23 & 48 \\
\hline Subjectivizer & & 2 & 2 & 1 & & & 5 \\
\hline Downtoner & & & 1 & & 1 & & 2 \\
\hline Cajoler & & 4 & & & 2 & & 6 \\
\hline Appealer & 1 & & 1 & 1 & & & 3 \\
\hline Scope-starter & 1 & & & & & & 1 \\
\hline $\begin{array}{c}\text { DOWNGRADERS } \\
\text { TOTAL }\end{array}$ & 14 & 9 & 30 & 19 & 7 & 29 & 108 \\
\hline \multicolumn{8}{|l|}{ Upgraders } \\
\hline Intensifier & 4 & 8 & 3 & 1 & 1 & & 17 \\
\hline $\begin{array}{l}\text { Commitment } \\
\text { indicator }\end{array}$ & 1 & & & 1 & 1 & & 3 \\
\hline Expletive & 1 & 1 & & & 1 & & 3 \\
\hline Time intensifier & 9 & 1 & 8 & & & 1 & 19 \\
\hline Lexical uptoner & & 3 & & & 4 & & 7 \\
\hline \multicolumn{8}{|l|}{ Determination marker } \\
\hline Emphatic addition & 3 & 1 & & & & & 4 \\
\hline $\begin{array}{c}\text { UPGRADERS } \\
\text { TOTAL }\end{array}$ & 18 & 14 & 11 & 2 & 7 & 1 & 53 \\
\hline $\begin{array}{c}\text { SUPPORTIVE } \\
\text { MOVES TOTAL }\end{array}$ & 32 & 23 & 41 & 21 & 14 & 30 & 161 \\
\hline
\end{tabular}

The English NSs used downgraders more frequently than upgraders (108 vs. 53). Moreover, downgraders were used regardless of the value of the variable $S$ (53 vs. 55), but there are some noticeable differences regarding the variable P. 
Downgraders were employed the most in the P-scenarios (in over $50 \%$ of cases with both $\mathrm{S}+$ and $\mathrm{S}-)$, with a notably lower use in the $\mathrm{P}+$ situations $(26.41 \%$ in $\mathrm{S}+$ and $34.55 \%$ in $\mathrm{S}-)$, and the least between status-equal $(\mathrm{P}=)$ interlocutors $(16.98 \%$ in $\mathrm{S}+$ vs. $12.73 \%$ in $\mathrm{S}-$ ). These findings can probably be ascribed to the fact that English NSs feel the need to mitigate their complaints when speaking to a person seen as an authority or a person of respect. The same need sometimes exists with inferior hearers, possibly to prevent them from perceiving the complainer as abusing their higher relative power. Using downgraders the least in $\mathrm{P}=$ scenarios shows that English NSs may feel most comfortable expressing their negative feelings to someone they perceive as their equal. The last thing to be noticed is that hedges were employed much more frequently than any of the other downgraders, again most noticeably in $\mathrm{P}+$ situations, whereas the politeness marker please is the second most-used supportive move. Other elements were less numerous. A couple of representative examples of English NS complaints are offered below.

1) Would you mind turning down your music? I am not feeling well.

2) Could you please put your pen down? Thank you.

3) You know, I lost a good job because you didn't give me the message.

4) Look I'm sorry, but this is not acceptable.

As opposed to downgraders, the use of which did not vary much regarding the variable $S$, upgraders were much more common in the $S+$ scenarios than the $S$ ones (43 vs. 10). However, those supportive moves were now employed the least in the $\mathrm{P}$ - situations (25.58\% in S+ and $10 \%$ in $\mathrm{S}$-). The most frequent use of upgraders is observed in the $\mathrm{P}+\mathrm{S}+$ scenarios (33.96\% of the overall use of upgraders), which could be interpreted as the speakers' need to stress the seriousness of the offense and to express concerns because the situations were such that the speaker would probably have to take at least partial responsibility for the consequences of the complainee's behavior. Intensifiers were also observed in the $\mathrm{P}=$ scenarios (especially in S+, $26.42 \%$ of the overall use), which again indicates that the English NSs felt free to express their dissatisfaction more strongly with someone perceived as their equal since the relationship between the interlocutors could be repaired more easily in such cases. The most frequently used upgraders were time intensifiers (especially (right) now) and intensifiers (especially really and very). Less numerous were commitment indicators, expletives, lexical uptoners, and emphatic addition. There were no instances of determination markers. The following responses illustrate how English NSs used upgraders in their responses: 
5) This is really going to be an issue.

6) I need the exams now, you need to get them now.

7) Why did you not write the message down? It was very important.

8) Damn! Now I have to cancel the meeting.

The distribution of supportive moves described above is not surprising because it suggests that English NSs tend to mitigate their complaints rather than intensify them when communicating with interlocutors who have power over them. To go even further, it can be pointed out that this is especially true in S- situations, which indicates that English NSs do not want to risk performing an FTA, possibly harming the relationship with a superior interlocutor, especially if this is due to a rather insignificant matter.

\subsection{Serbian NSs}

As for the Serbian NSs, the frequency of supporting moves varied. There were a total of 242 such elements, 10.08 per participant (compared to 12.38 per English NS participant). All the numbers are available in the table below.

Table 4. Supportive moves in the complaints of the Serbian NSs

$$
\begin{aligned}
& \text { High offense (S+) } \\
& \text { Low offense (S-) }
\end{aligned}
$$

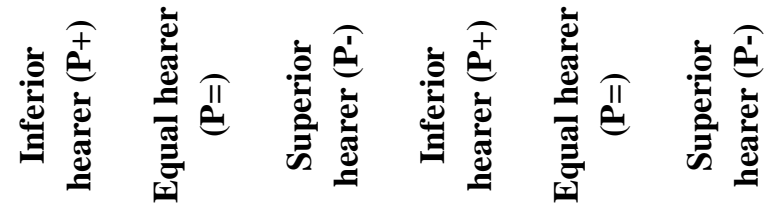

\begin{tabular}{cccccccc}
\hline Downgraders & & & & & & & \\
\hline Politeness marker & 13 & 1 & 13 & 17 & 4 & 8 & 56 \\
\hline Understater & 1 & 1 & 5 & 2 & 3 & 10 & 22 \\
\hline Hedge & 1 & 3 & 18 & 4 & 3 & 31 & 60 \\
\hline Subjectivizer & 1 & & & 1 & 3 & 2 & 7 \\
\hline Downtoner & & & & & 1 & & 1 \\
\hline Cajoler & 1 & & 1 & & & & 1 \\
\hline Appealer & 1 & & $\mathbf{3 7}$ & $\mathbf{2 4}$ & $\mathbf{1 4}$ & $\mathbf{5 2}$ & $\mathbf{1 5 0}$ \\
\hline Scope-starter & $\mathbf{1 8}$ & $\mathbf{5}$ & & & & & \\
\hline $\begin{array}{c}\text { DOWNGRADERS } \\
\text { TOTAL }\end{array}$ & & 13 & 7 & 3 & 1 & 5 & 37 \\
\hline Upgraders & 8 & 1 & 2 & & & 3 \\
\hline Intensifier & & &
\end{tabular}




\begin{tabular}{cccccccc}
\hline indicator & & & & & & & \\
\hline Expletive & 2 & 5 & & & & 1 & 1 \\
\hline Time intensifier & 6 & 1 & 8 & & 5 & & 17 \\
\hline Lexical uptoner & 4 & 1 & & 4 & 14 & 3 \\
\hline Determination marker & 1 & 1 & 1 & & & & 11 \\
\hline Emphatic addition & 6 & 1 & & 2 & 2 & $\mathbf{9 2}$ \\
\hline $\begin{array}{c}\text { UPGRADERS } \\
\text { TOTAL }\end{array}$ & $\mathbf{2 7}$ & $\mathbf{2 2}$ & $\mathbf{1 7}$ & $\mathbf{1 1}$ & $\mathbf{9}$ & $\mathbf{6}$ & $\mathbf{9 2}$ \\
\hline $\begin{array}{c}\text { SUPPORTIVE } \\
\text { MOVES TOTAL }\end{array}$ & $\mathbf{4 5}$ & $\mathbf{2 7}$ & $\mathbf{5 4}$ & $\mathbf{3 5}$ & $\mathbf{2 3}$ & $\mathbf{5 8}$ & $\mathbf{2 4 2}$ \\
\hline
\end{tabular}

The Serbian NSs used 150 downgraders and 92 upgraders. The English NSs also employed downgraders more, so it is something these groups share. Furthermore, these elements were used more in the $\mathrm{S}$ - than in the $\mathrm{S}+$ situations. They were mostly found with $\mathrm{P}-$, to a somewhat lesser extent with $\mathrm{P}+$, and significantly less often with $\mathrm{P}=$. It seems the Serbian NSs made an effort to present their complaints aimed at superior hearers as less aggressive, whereas the least amount of mitigation was used with equal interlocutors. The participants probably felt the consequences would be more serious if they did not modify their complaints to prevent the complainee from feeling threatened. Mitigating was predominantly achieved by employing hedges (mostly through constructions such as Možeš li (Can you), Da li biste mogli (Could you), Voleo bih (I'd like to), among others) and the politeness marker molim te/Vas (please)). Understaters were also common - mostly malo (a bit) and možda (maybe) - whereas the rest of the downgraders were much less numerous. The following examples are some of the responses the Serbian NSs provided:

9) Da li možete da mi kažete na osnovu čega se utvđuje iznos božićnog dodatka?

Could you tell me how the Christmas bonus is calculated?

10) Izvinite, čekaću koliko treba, ali samo bih da proverim da znate da sam tu. Excuse me, I will wait as long as necessary, but I would just like to make sure you know I am here.

11) Sledeći put samo malo skloni iza sebe.

Next time, just tidy up a bit before you leave.

12) Izvinite, profesore, nije mi stigao mejl sa rezultatima ispita. Da li se možda sećate kako sam uradila ispit?? 
Excuse me, professor, I have not received an email with the exam results. Do you remember by any chance how I did in the exam?

The use of upgraders, however, exhibited a different tendency. Upgraders were used considerably more often with S+ than S- (66 vs. 26 occurrences), indicating that the speakers felt the need to underscore the seriousness of offense and its potential consequences. With both S+ and S-, the amount of intensification was directly proportional to the perceived power of the hearer. This means the speakers opted for strengthening the impact of their complaints the most when they felt they had more power over the complainees $(41.30 \%$ of the overall use of upgraders). Contrastively, the Serbian participants avoided intensifying their complaints when addressing an offense committed by someone superior. The most widely used upgraders were intensifiers (mostly baš/veoma/jako=really/ indeed/very), followed by time intensifiers, such as odmah (immediately) and što pre (as soon as possible). Other elements were much less frequent.

13) To je veoma neodgovorno od Vas. Idite sada da umnožite testove.

That is very irresponsible of you. Now go and make copies of the test.

14) Onda to ti objasni profesoru. Baš si nemaran.

Then you explain it to the professor. You're so careless.

15) Tata, to mi je jako važno. Sledeći put kad ti kažem molim te da to odmah uradiš.

Dad, it is very important to me. Next time I tell you, please do it immediately.

16) Stvarno nije u redu što ste bacili te papire, ko vam je rekao da to uradite?

It is really not ok that you threw away those papers; who told you to do it?

To reiterate, the Serbian NSs used downgraders more than upgraders, much like the English NSs. Both groups' complaints most commonly involved hedges and the politeness marker please, and the overall use of downgraders was more prominent when interacting with superior participants. Therefore, both Serbian and English NSs mitigate their complaints aimed at people having power over them. Both groups used downgraders least frequently when complaining to an equal interlocutor. English and Serbian NSs thus express their dissatisfaction in a more softened manner with people representing an authority figure, probably to avoid more serious consequences to their relationship with the hearer. For that reason, it 
was not surprising to find that the two groups employed upgraders the most with inferior hearers and the least with superior ones.

When Prodanović (2014) investigated this speech act, her scenarios involved equal participants only, therefore the present results can only be compared to hers in that respect. In addition, Prodanović analyzed her data based on a different classification of modifiers. However, her findings are similar to ours in the sense that the politeness marker molim te (please) and hedges in the form of modal verbs (mostly moci (could)) were the most numerous, and intensifiers such as stvarno (really), tako (so), and veoma (very) also occurred frequently in her corpus.

\subsection{Advanced Serbian EFL learners}

Finally, an overview of the use of supportive moves in complaints produced by the advanced Serbian EFL learners is presented in the table below.

Table 5. Supportive moves in the complaints of the advanced Serbian EFL learners

\begin{tabular}{|c|c|c|c|c|c|c|c|}
\hline & \multicolumn{3}{|c|}{ High offense (S+) } & \multicolumn{3}{|c|}{ Low offense (S-) } & \multirow[b]{2}{*}{ TOTAL } \\
\hline & 离 & 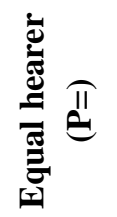 & 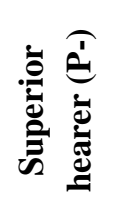 & 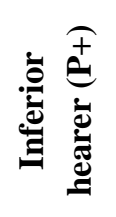 & 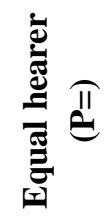 & 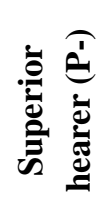 & \\
\hline \multicolumn{8}{|l|}{ Downgraders } \\
\hline Politeness marker & 23 & 4 & 29 & 25 & 5 & 25 & 111 \\
\hline Understater & & & 2 & 3 & 1 & 5 & 11 \\
\hline Hedge & 3 & 2 & 28 & 9 & 2 & 36 & 80 \\
\hline Subjectivizer & 2 & 3 & 2 & 3 & & & 10 \\
\hline Downtoner & 4 & & 1 & & & & 5 \\
\hline Cajoler & & & & 2 & 2 & & 4 \\
\hline Appealer & 1 & & & 1 & & & 2 \\
\hline Scope-starter & 1 & & & & 1 & & 2 \\
\hline $\begin{array}{c}\text { DOWNGRADERS } \\
\text { TOTAL }\end{array}$ & 34 & 9 & 62 & 43 & 11 & 86 & 245 \\
\hline \multicolumn{8}{|l|}{ Upgraders } \\
\hline Intensifier & 7 & 14 & 11 & 3 & 2 & 3 & 40 \\
\hline $\begin{array}{l}\text { Commitment } \\
\text { indicator }\end{array}$ & 1 & 1 & & 1 & & & 3 \\
\hline Expletive & & 3 & & & 4 & & 7 \\
\hline Time intensifier & 11 & & 13 & 1 & 2 & 3 & 30 \\
\hline Lexical uptoner & & 2 & 1 & & 10 & & 13 \\
\hline
\end{tabular}




\begin{tabular}{cccccccc}
\hline Determination marker & & & 1 & & 1 & & 2 \\
\hline Emphatic addition & 5 & & & & & & 5 \\
\hline $\begin{array}{c}\text { UPGRADERS } \\
\text { TOTAL }\end{array}$ & $\mathbf{2 4}$ & $\mathbf{2 0}$ & $\mathbf{2 6}$ & $\mathbf{5}$ & $\mathbf{1 9}$ & $\mathbf{6}$ & $\mathbf{1 0 0}$ \\
\hline $\begin{array}{c}\text { SUPPORTIVE } \\
\text { MOVES TOTAL }\end{array}$ & $\mathbf{5 8}$ & $\mathbf{2 9}$ & $\mathbf{8 8}$ & $\mathbf{4 8}$ & $\mathbf{4 0}$ & $\mathbf{9 2}$ & $\mathbf{3 4 5}$ \\
\hline
\end{tabular}

While producing complaints (as many as 15.68 per participant), the advanced Serbian EFL learners relied more on downgraders (245) than upgraders (100), just as the other two groups. Supporting moves were used similarly regarding the $\mathrm{S}+/ \mathrm{S}$ - distinction (175 vs. 180 ).

Focusing on downgraders, the respondents used them more in the Ssituations, indicating that they tried to soften their complaints more if the offense was less serious, which was quite unexpected. As for the variable $\mathrm{P}$, downgraders were mostly found in the P- situations (more precisely, $59.05 \%$ of the $\mathrm{S}+$ and $61.43 \%$ of the S- situations). Contrastively, downgraders were used the least in the $\mathrm{P}=$ scenarios $(8.57 \%$ in $\mathrm{S}+$ and $7.86 \%$ in $\mathrm{S}$ - situations). The politeness marker please was the most frequent downgrader, followed by hedges. Other downgraders were less common. The four examples below illustrate the complaint production of the EFL group of research participants, as they occurred in the questionnaires:

17) I would be grateful if you could write an explanatory note for the library.

18) Would you mind turning down the music a little bit, please? I have a horrible headache and I could use a little rest.

19) For some reason, I didn't receive the email with final exam marks. Could you, please, send them to me as well?

20) Excuse me, I'm not on the list, and I was wondering if you maybe skipped me by accident?

As opposed to downgraders, upgraders occurred more frequently in the $\mathrm{S}+$ situations (70 vs. a mere 30 occurrences with S-), which means the respondents felt the need to emphasize their negative evaluation of the situation when the offense was viewed as serious. The difference in the use of upgraders with respect to the variable $\mathrm{S}$ is not particularly significant, but these elements were used slightly more often in the scenarios which depicted status-equal $(\mathrm{P}=)$ interlocutors (39\%) compared to the $\mathrm{P}+$ scenarios (29\%) and the $\mathrm{P}$ - ones (32\%), which makes this group different from the previous two (the English NSs and Serbian NSs used upgraders the most in the $\mathrm{P}+$ situations and the least in the $\mathrm{P}=$ situations). This could be 
explained by the fact that the advanced Serbian EFL learners in this study were somewhat younger than the participants in the other two groups, so they probably have not experienced many real-life situations in which they were a superior interlocutor (employer/professor/parent), which makes these situations more hypothetical for them. Overall, however, intensifiers (especially really/very) and time intensifiers (such as (right) now, asap, right away) were predominantly employed, much like in the other two groups, a shown in the examples below:

21) This was really important. I am really angry.

22) Dad, send me the money as soon as possible, it's a matter of life and death.

23) Clean this up, right now.

24) You need to come back here and take care of your mess.

What all three groups have in common is that downgraders were used more than upgraders, especially in low offense scenarios. Moreover, all three groups used those elements the most with superior hearers and the least with equal ones. Both cultures seem to share the view that it is not (always) necessary to soften complaints to equal hearers, but it is best to do so with superior ones in order not to threaten the interlocutor's face. As for upgraders, the two NS groups had similar performance, while the Serbian EFL learners performed somewhat differently, indicating that the difference is most likely to be ascribed to a non-cultural factor. In other words, even though generally, "adult learners rely on universal or L1 based pragmatic knowledge" (Kasper 2001: 511) and they "by default transfer their L1 conventions and judgments to L2 encounters" (Glaser 2009: 54), this is not always the case. In some situations, when they suspect that the target linguistic and cultural conventions might differ from the $\mathrm{L} 1$ ones, they are prone to producing speech acts which do not conform either to the L1 or the target language conventions. However, a lot more research into this domain is needed in order to draw sound conclusions regarding this matter.

\section{CONCLUSION}

This paper explores direct, face-to-face complaints produced by NSs of Serbian, NSs of English, and advanced Serbian EFL learners. More specifically, it focuses on supportive moves and analyses them drawing on the taxonomy offered by House \& Kasper (1981) and taking into account the social variables of power and severity of offense. The findings confirm the hypothesis that the two cultures would not differ widely concerning the way their representatives produce 
complaints. What might nevertheless be considered as an example of pragmatic transfer is the unexpected tendency of the Serbian EFL learners to soften their complaints more in case of a trivial offense than a rather severe one - a phenomenon observed in the Serbian NS group, as well. Other than that, it appears that the EFL group exhibited an acceptable level of pragmatic competence. This means that their performance can have two interpretations - it is either seen as similar to the performance of the English NS group and the learners' pragmatic competence really is at a level close to their linguistic competence or else, given that the two cultures are similar with respect to this aspect of complaining, it might be seen as following the Serbian NS conventions and involving transfer from the learners' L1. Either way, the importance of teaching L2 pragmatics must be emphasized again so that all EFL learners and especially future teachers like the EFL participants in this research can be equipped with the best tools possible for using and teaching L2 language and culture successfully.

Milica Lukić, Sabina Halupka-Rešetar

POMOĆNI IZRAZI U GOVORNOM ČINU DIREKTNE ŽALBE U ENGLESKOM I SRPSKOM JEZIKU: MEĐUKULTURNA I MEĐUJEZIČKO-PRAGMATIČKA ANALIZA

Rezime

Cilj ovog istraživanja je analiza pomoćnih izraza u govornom činu direktne žalbe kod izvornih govornika engleskog i srpskog jezika kako bi se ustanovile sličnosti i razlike između pripadnika dve kulture pri izvođenju pomenutog govornog čina na maternjem jeziku. Istraživanje takođe uključuje studente engleskog jezika na visokom nivou znanja čiji je maternji jezik srpski kako bi se istražila njihova pragmatička kompetencija u stranom jeziku, naročito mera u kojoj je uočljivo oslanjanje na pragmatičke konvencije maternjeg jezika u produkciji govornog čina direktne žalbe na stranom (engleskom) jeziku. Naime, ovi studenti su realizovali svoje žalbe na engleskom, jeziku kojem su izloženi tokom čitavih studija, ali kod svih učenika stranog jezika postoji mogućnost oslanjanja na maternji kada pragmatičke norme ciljnog jezika nisu usvojene u dovoljnoj meri (pragmatički transfer).

Podaci su prikupljeni putem testa dopune diskursa u pisanom obliku i analizirani na osnovu klasifikacije koju su ponudili House i Kasper (1981). Autori predlažu dve vrste pomenutih elemenata (jedni pojačavaju efekat izraza, dok ga drugi ublažavaju), koji se dalje dele na podgrupe. Analiza takođe uključuje dve varijable: relativna društvena moć sagovornika (jednaki ili nejednaki govornici) i ozbiljnost prekršaja (više ili manje ozbiljan). 
Rezultati istraživanja su pokazali da je upotreba pomoćnih izraza kod izvornih govornika engleskog i srpskog jezika u velikoj meri slična. Žalbe se najčešće ublažavaju u komunikaciji sa osobama koje imaju veću društvenu moć (profesori, nadređeni na poslu, roditelji, itd), a najređe sa osobama koje imaju jednaku društvenu moć (prijatelji, kolege, vršnjaci, itd). Najčešće korišćeni pomoćni elementi bile su diskursne ograde (modalni glagoli, izvinjenja, itd) i izraz molim te/Vas (please). Efekat žalbe najčešće je pojačavan u komunikaciji sa osobama koje imaju manju društvenu moć (podređeni na poslu, učenici, mlađi komšija i sl), uglavnom koristeći izraze poput što pre (as soon as possible), odmah (right away), stvarno (really), tako (so) i veoma (very).

Srpski studenti engleskog na visokom nivou znanja postigli su slične rezultate, s tim da je kod ove grupe nešto dominantnije pojačavanje efekta žalbe pri komunikaciji sa statusno jednakim govornicima. Kako su prethodne dve grupe ostvarile gotovo identične rezultate, teško je suditi o pragmatičkoj kompetenciji ove grupe ispitanika. Ipak, kao primer mogućeg pragmatičkog transfera izdvaja se činjenica da su ovi ispitanici, isto kao i grupa izvornih govornika srpskog jezika, nešto češće ublažavali žalbe u situacijama gde je prekršaj bio manje ozbiljan. U svakom slučaju, važno je istaknuti koliko je značajno da učenici stranog jezika - naročito ako su mahom budući predavači tog jezika, poput učesnika u ovom istraživanju - steknu visok nivo pragmatičke kompetencije u stranom jeziku, što se može postići uz eksplicitno podučavanje, koristeći prikladne i autentične materijale kako bi razvijali ne samo znanje o gramatici i vokabularu nego i pragmatičku kompetenciju, što je glavni preduslov za uspešnu komunikaciju na bilo kom jeziku.

Ključne reči: govorni činovi, žalba, pomoćni izrazi, engleski jezik, srpski jezik, srpski studenti engleskog na visokom nivou znanja

\section{REFERENCES}

Al-Tayib Umar, A. M. (2006). The Speech Act of Complaint as Realized by Advanced Sudanese Learners of English. Umm Al-Qura University Journal of Educational \& Social Sciences \& Humanities, 18(2), 8-40.

Austin, J. L. (1962). How to do things with words. Oxford: Clarendon Press.

Brown, P.-Levinson, S. C. (1987). Politeness: Some universals in language usage. Cambridge: Cambridge University Press.

Crystal, D. (1997). English as a global language. Cambridge: Cambridge University Press.

Eshraghi, A.-Shahrokhi, M. (2016). The Realization of Complaint Strategies among Iranian Female EFL Learners and Female Native English Speakers: A Politeness Perspective. International Journal of English Linguistics, 6(2), 9-20. 
Glaser, K. (2009). Acquiring pragmatic competence in a foreign language: Mastering dispreferred speech acts. Topics in Linguistics, 4, 50-57.

House, J.-Kasper, G. (1981). Politeness Markers in English and German. In: Coulmas, F. (Ed.) (1981). Conversational Routines. The Hague: Mouton de Gruyter. 157-185.

Kasper, G.-Dahl, M. (1991). Research Methods in Interlanguage Pragmatics. Studies in Second Language Acquisition, 13(2), 215-247.

Kasper, G. (2001). Four perspectives on L2 pragmatic development. Applied linguistics, 22(4), 502-530.

Olshtain, E.-Weinbach, L. (1993). Interlanguage features of the speech act of complaining. In: Kasper, G. \& Blum-Kulka, S. (eds.) (1993). Interlanguage pragmatics. New York: Oxford University Press. 108-122.

Piotrowska, M. (1987). An Investigation into the Sociolinguistic Competence of Hong Kong University Students with Specific Reference to Making Complaints (Unpublished master's thesis). Hong Kong University.

Prodanović, M. (2014). Kontrastivna analiza sredstava za ublažavanje govornih činova koji ugrožavaju obraz sagovornika u engleskom i srpskom jeziku. [Contrastive Analysis of Mitigation Devices in Face-threatening Acts in English and Serbian]. (Doctoral dissertation). Faculty of Philology, University of Belgrade.

Prodanović, M. (2016). Raising Pragmatic Awareness in Second Language Acquisition: Comparison of Non-Native and Native Complaints. In: Akbarov, A. (Ed.) (2016). Current Research on Language Learning and Teaching: Case Study of Bosnia and Herzegovina. Newcastle upon Tyne: Cambridge Scholars Publishing. 181-195.

Searle, J. R. (1969). Speech acts: An essay in the philosophy of language. Cambridge: Cambridge University Press.

Searle, J. R. (1975). Indirect Speech Acts. In: Cole, P. \& Morgan, J. L. (eds.) (1975). Syntax and Semantics, 3. New York, London: Academic Press. 5982.

Searle, J. R. (1976). A classification of illocutionary acts. Language in Society, 5, 123. Retrieved from: http://dx.doi.org/10.1017/S0047404500006837

Tanck, S. (2002). Speech Act Sets of Refusal and Complaint: A Comparison of Native and Non Native English Speakers' Production. Studies in Second Language Acquisition, 13, 65-81.

Trosborg, A. (1995). Interlanguage pragmatics: Requests, complaints, apologies. New York: Mouton De Gruyter. 
Trosborg, A. (2011). Interlanguage pragmatics: Requests, complaints, and apologies. Berlin: Mouton de Gruyter. 


\section{APPENDIX}

The questionnaires used are available at:

1) the English version: http://tiny.cc/82loiz

2) the Serbian version:http://tiny.cc/g5loiz 